\title{
Bifid canals: identification of three clinical cases using cone-beam computed tomography images
}

Canais bifidos: identificação de três casos por meio de imagens de tomografia computadorizada de feixe cônico

\author{
Paulo de Camargo MORAES 1 \\ (i) ORCID iD 0000-0001-5069-4600 \\ Daniela Prata TACCHELLI ${ }^{1}$ \\ (iD) ORCID iD 0000-0003-0907-1174 \\ Rubens Gonçalves TEIXEIRA ${ }^{1}$ \\ (i) ORCID iD 0000-0003-0814-0940 \\ Luciana Butini OLIVEIRA ${ }^{1}$ \\ (iD) ORCID iD 0000-0002-8755-6540 \\ José Luiz Cintra JUNQUEIRA ${ }^{1}$ \\ (D) ORCID iD 0000-0001-6788-4021
}

\begin{abstract}
Anatomical variations of mandibular canal have rarely been reported in the literature. The aim of this paper is to present three clinical cases of bifid mandibular canal diagnosed with cone-beam computed tomography (CBCT) as well as discuss its clinical implications. The first case is very interesting due to its anatomic variation verified in a panoramic radiograph during orthodontic planning, mimicking an odontogenic tumor. The second and the third cases were identified during tomographic evaluation for third molar exodontia. The diagnosis of bifid canals is extremely relevant in order to avoid complications during surgical procedures and implant placement as well as anesthesia failures which cause pain, paresthesia and bleeding. Furthermore, the shape of these anatomical variations can be confused with bone lesions.
\end{abstract}

Indexing terms: Mandibular Nerve. Surgery, Oral. Diagnosis.

\section{RESUMO}

O objetivo deste trabalho é apresentar três casos clínicos de canais mandibulares bífidos, diagnosticados em imagens de tomografia computadorizada de feixe cônico (TCFC) e discutir as possíveis implicações clínicas destas variações. O primeiro caso relatado é bastante interessante devido à variação anatômica diagnosticada em uma radiografia panorâmica, indicada para o planejamento ortodôntico. A ocorrência do canal bífido mimetiza o aspecto de um tumor odontogênico. A presença de canal bífido no segundo e no terceiro caso clínico foi identificada durante a avaliação tomográfica para a exodontia de terceiros molares. O diagnóstico de canais bífidos é de grande relevância para evitar possíveis complicações durante a realização de cirurgias, instalação de implantes dentários e falhas de anestesias durante os procedimentos cirúrgicos que podem provocar dor, parestesia e sangramento. Além disso, estas variações anatômicas podem ser confundidas com lesões ósseas.

Termos de indexação: Diagnóstico. Cirurgia bucal. Nervo mandibular.

\section{INTRODUCTION}

During the seven week of the uterine life the inferior alveolar nerve divides into mental and incisive branches that can show anatomic variant along its trajectory [1]. Originally, the mandibular canal transmits to the inferior alveolar artery a third division branch of the trigeminal nerve. The term bifid is derived from a Latin word meaning a cleft into two parts or branches [2].
The first case of bifid mandibular canal was published by Patterson and Funk in 1973 [3]. The authors described a case of unilateral mandibular canal with two mental foramina which was shown in a panoramic and lateral jaw radiographs. A previous report had shown a case of trifid mandibular canal diagnosed during a preimplant radiographic evaluation [4].

Taking into consideration the anatomic variations and their implications during surgical procedures,

\footnotetext{
${ }^{1}$ Faculdade São Leopoldo Mandic, Instituto de Pesquisa São Leopoldo Mandic. Rua José Rocha Junqueira, 13, Bairro Swift, Campinas - SP, Brasil, CEP: 13045-755. Correspondência para / Correspondence to: PC Moraes E-mail:< paulo.moraes@slmandic.edu.br>.

$\mathbf{\nabla} \mathbf{v}$.

Como citar este artigo / How to cite this article

Moraes PC, Tacchelli DP, Teixeira RG, Oliveira LB, Junqueira JLC. Bifid canals: identification of three clinical cases using cone-beam computed tomography images. RGO, Rev Gaúch Odontol. 2018;66(3):263-266. http://dx.doi.org/10.1590/1981-8637201800030000113693
} 
knowledge of bifid canals is paramount for dental surgeons [5-7]. The occurrence of bifid mandibular canal is extremely variated in the dental literature. A review made by Sanchis et al.8 of 2,012 panoramic radiographs during 1996 to 1999 resulted in 1,276 women and 736 men (mean age 40.4 years). Only 7 cases $(0.35 \%$ ) were found in radiographic images suggesting double mandibular canal, three of them were confirmed by computed tomography images. A previous study [9] had reported that $0.08 \%$ of radiographs presented a double canal. Langlais et al. [10] found $0.95 \%$ of bifid mandibular canals. Nortje et al. [11] found $0.9 \%$ in 3,612 panoramic radiographs. Zografos et al. [12] found $0.4 \%$ to the incidence during 700 panoramic evaluations. Moreover, there are different classifications of the mandibular canal variations proposed by Carter \& Keen [13], Nortje et al. [11] and Langlais et al. [10].

The present paper reports three cases of bifid canals using cone-beam computed tomography (CBCT).

\section{CASE REPORTS}

\section{Case 1}

A 21-year-old female was referred to the dental office for a routine dental appointment and orthodontic treatment and the dentist asked her for a panoramic radiography.

After the radiographic analysis, the dentist verified an oval, painless, well delimited radiopacity area in the left mandibular ramus which showed a sclerotic halo near the mandibular canal. A computed tomography was performed and to our surprise, there was a bifid mandibular canal, mimicking an odontogenic tumor. The tomography showed an arm-shaped, dense image, diverting from the mandibular canal reaching the left alveolar crist (Figure1). The patient was elucidated and oriented to continue an orthodontic treatment.

\section{Case 2}

A 33-year-old male was referred for a CBCT scan due to third molars exodontia and during the radiographic examination a radiographic image was observed which suggested a manbibular bifid canal near to the right mandibular foramen.

A cone beam tomography image was asked in order to confirm the alteration and planning the third molar surgery (Figure 2).
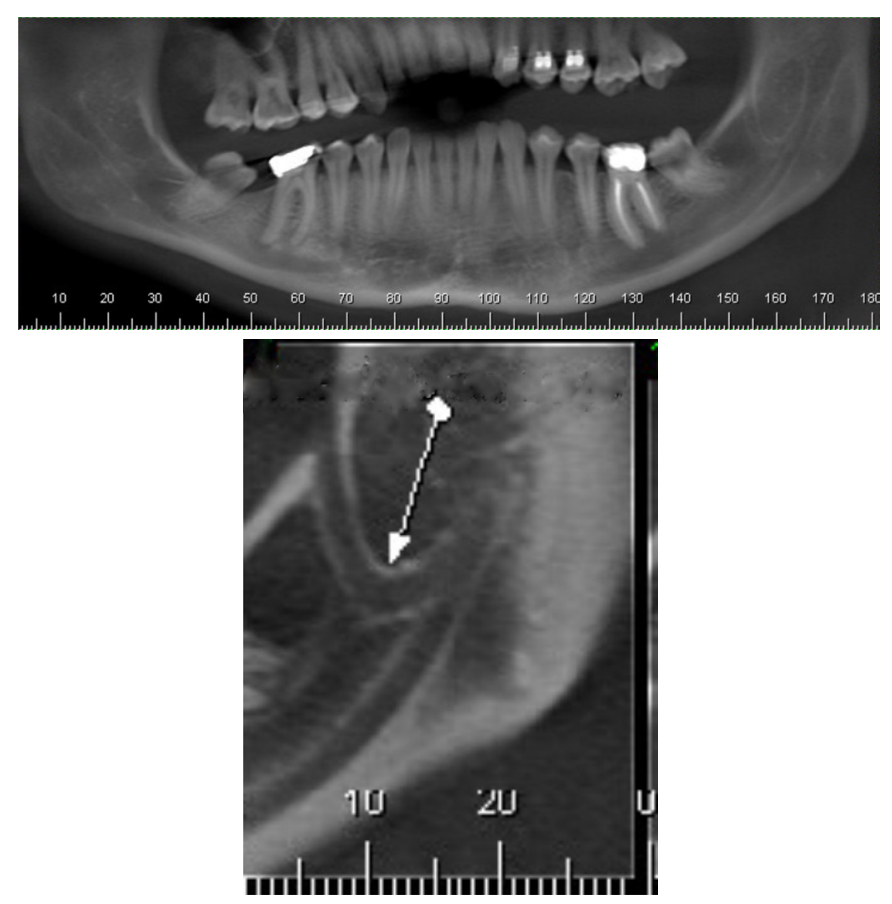

Figure 1. Panoramic reconstruction of $C B C T$ image $(A)$ and a cropped panoramic $\mathrm{CBCT}$ (B) demonstrating the bifid mandibular canal mimicking an odontogenic tumor.
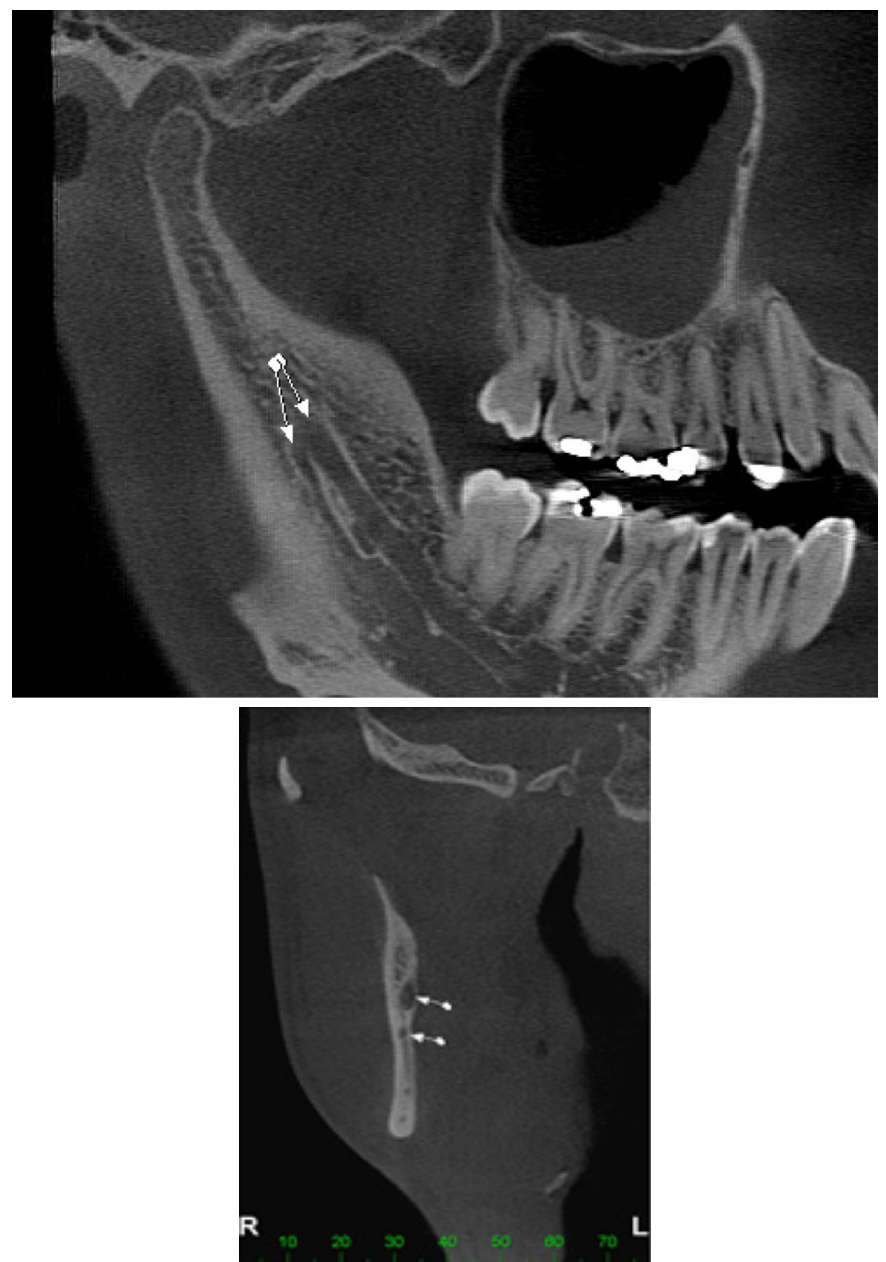

Figure 2. A and B. White arrows showing the bifid mandibular canal on CBCT images 


\section{Case 3}

A 32-year-old female was referred for third molar exodontia due to recurrences of pericoronaritis. During the surgical planning, the panoramic radiograph showed an alteration of mandibular canal in the near the apex of third molar suggesting a bifid mandibular canal that was confirmed during a cone-beam computed tomography evaluation (Figure 3). No anesthesia failure was observed and surgery procedures were painless, with no bleeding during the transoperative period.
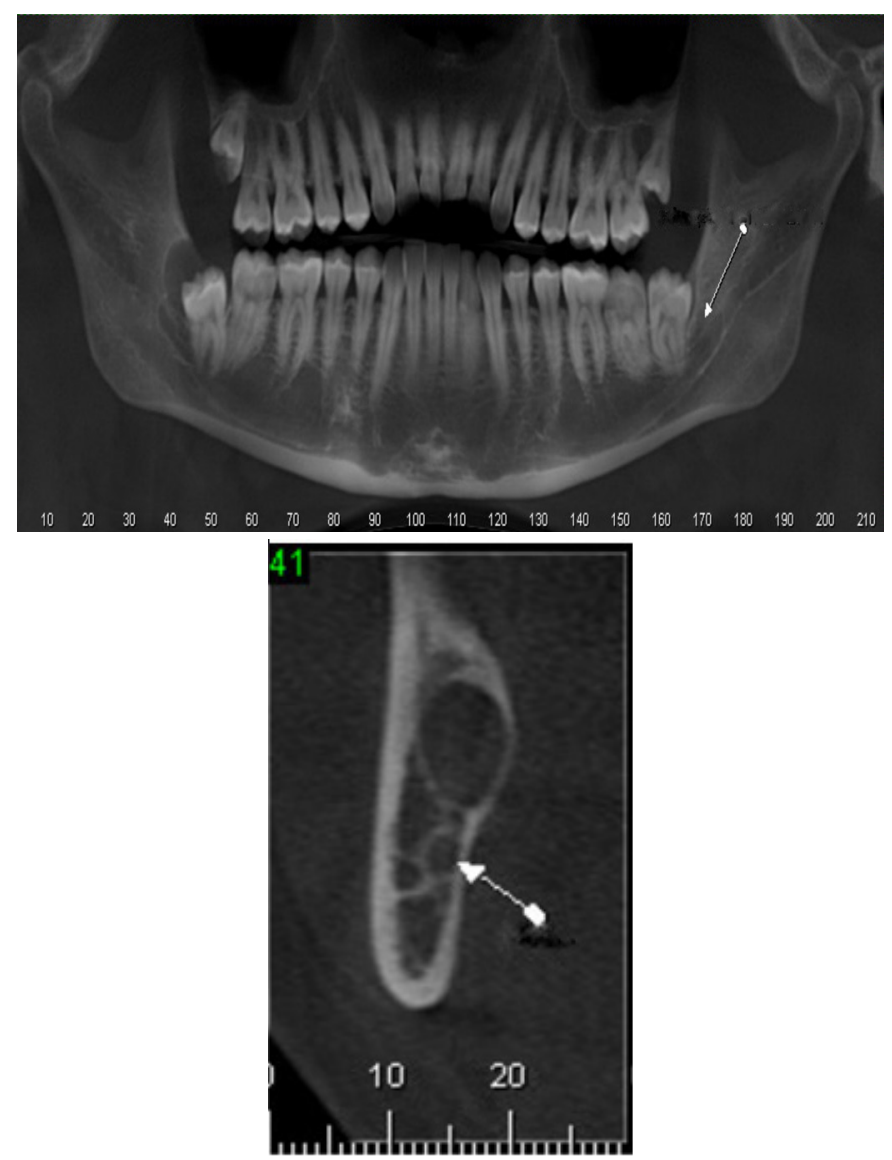

Figure 3. $A$ and B) White arrows showing the bifid mandibular canal on CBCT exams.

\section{FINAL CONSIDERATIONS}

The anatomic variation of mandibular canal is possible once the alveolar nerve can be divided during embryologic formation and bifid or trifid canal have been reported in the dental literature $[1,2,4]$.

\section{REFERENCES}

1. Wadhwani P, Mathur RM, Kohli, M, Sahu R. Mandibular canal
Some authors [4] reported a case of trifid mandibular canal discovered during treatment planning for dental implant placement. The incidence of bifid or trifid, unilateral or bilateral anatomic variations of mandibular nerve is extremely diversified in the literature, presenting $0.35 \%$ to $0.95 \%$ in panoramic radiographs evaluation [8$12,14]$. A recent systematic review [15] has shown that the frequency variations of the mandibular canal through assessing in situ, panoramic radiography and CT or CBCT were $6.46 \%, 4.20 \%$ and $16.25 \%$, respectively.

Anesthesia failures and other important complications during surgical procedures have been reported in the literature5,6. In addition bifid canals pose a challenge and can lead to difficulties while performing implant surgery in the mandible. Bifid canals can be diagnosed with panoramic radiography and more accurately with cone beam computerized tomography$\mathrm{CBCT}$. Previous studies have reported that the diagnosis is confirmed with cone-beam tomography and multislice tomography $[2,14,14]$. Naitoh et al. [7] compared the two modalities of tomography for the vascular alteration diagnosis and concluded that both can be used for these diagnosis confirmation. However, some authors have stated that conventional panoramic radiograph cannot identify the bifid canal [16].

\section{CONCLUSION}

In conclusion, the importance of the mandibular canal anatomic variation is essential, so that the dentist can be aware of anesthesical failures and complications during surgical procedures that can be painful, trigger paresthesia and bleeding. Moreover, depending on the anatomical variation shape it can be confused with a bone lesion.

\section{Collaborators}

PC MORAES, DP TACCHELLI and RG TEIXEIRA assisted the patients and were in charge of writing the draft of the paper. LB OLIVEIRA and JLC JUNQUEIRA critically revised and wrote the paper. All authors approved the final version to be published.

variant: a case report. J Oral Pathol Med. 2008 Feb;37(2):122-4. doi: 10.1111/j.1600-0714.2007.00573.x

2. Claeys V, Wackens G. Bifid mandibular canal: literature review and case report. Dentomaxillofac Radiol. 2005 Jan;34(1): 55-8. 
doi: $10.1259 / \mathrm{dmfr} / 23146121$

3. Patterson JE, Funk FW. Bifid inferior alveolar canal. Oral Surg Oral Med Oral Pathol. 1973 Aug;36(2):287-8.

4. Auluck A, Pai KM. Trifid mandibular nerve canal. Dentomaxillofac Radiol. 2005 July;34(4):259.

5. Lew K, Townsen G. Failure to obtain adequate anaesthesia associated with a bifid mandibular canal: a case report. Aut Dent J. 2006;51(1):86-90. doi: 10.1111/j.1834-7819.2006. tb00406.x

6. Karamifar K, Shahidi S, Tondari A. Bilateral Bifid mandibular canal: report of two cases. Indian J Dent Res. 2009;20(2):2357. doi: 10.4103/0970-9290.52889

7. Naitoh M, Nokahara K, Suenaga Y, Gotoh K; Ariji E. Comparison between cone-beam tomography depicting mandibular neurovascular canal structures. Oral Surg Oral Med Oral Pathol Oral Radiol Endod. 2010 Jan;109(1): e25-31. doi: 10.1016/j. tripleo.2009.08.027

8. Sanchis JM, Peñarrocha M, Soler F. Bifid mandibular canal. J Oral Maxillofac Surg. 2003;61(4):422-4. doi: 10.4081/cp.2016.881

9. Grover PS, Lorton L. Bifid mandibular nerve as a possible cause of inadequate anesthesia in the mandible. J Oral Maxillofac Surg. 1983 Mar;41(3):177-9. doi: 10.1016/0278-2391(83)90076-9

10. Langlais RP, Broados R, Glass BJ. Bifid mandibular canals in radiographs. J Am Dent Assoc. 1985 Jun;110(6):923-6. doi: 10.14219/jada.archive.1985.0033
11. Nortjé CJ, Farman AG, Grotepass FW. Variations in the normal anatomy of the inferior dental (mandibular) canal: a Retrospective study of panoramic radiographs from 3612 routine dental patients. Br J Oral Surg. 1977 Jul;15(1):55-63.

12. Zografos J, Kolokoudias M, Papadakis E. The types of mandibular canal. Hell Period Stomat Gnathopathoprosopike Cheir. 1990 Mar;5(1):17-20.

13. Carter RB, Keen EN. The intramandibular course of the inferior alveolar nerve. J Anat. 1971;108:433-40.

14. Miloglu O, Yilmaz A, Caglayan F. Bilateral bifid mandibular canal: a case report. Med Oral Pathol Oral Cir Bucal 2009; 14:E 244-6.

15. Hass LF, Dutra K, Porporatti AL, Mezzomo LA, De Luca Canto G, Flores-Mir C, et al. Anatomical variations of mandibular canal detected by panoramic radiography and $\mathrm{CT}$ : a systematic review and meta-analysis. Dentomaxillofac Radiol. 2016;45:20150310.

16. Yeong-Hoon K, Hun-Mu Y. Conventional panoramic radiograph cannot identify the bifid canal. J Craniofac Surg. 2015 Oct;26(7):e674-5. doi: 10.1097/SCS.0000000000002058
Received on: 20/4/2018

Final version resubmitted on: 14/5/2018

Approved on: 11/9/2018 